$$
\begin{aligned}
& \text { قسم طب الحيوان } \\
& \text { كلية الطب البيطري - جامعة أسيوط }
\end{aligned}
$$

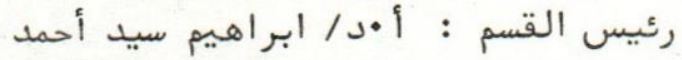

$$
\begin{aligned}
& \text { نمط التحليل الكهربي لبروتينات مصل الدم في حالات } \\
& \text { تنكرز الكبد في الأننام } \\
& \text { علي السباعي ، أحمد عامر }
\end{aligned}
$$

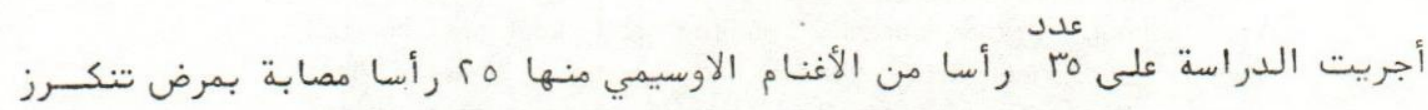

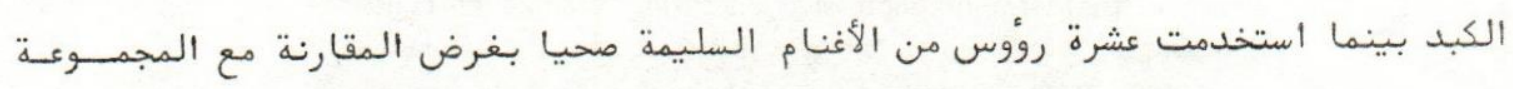

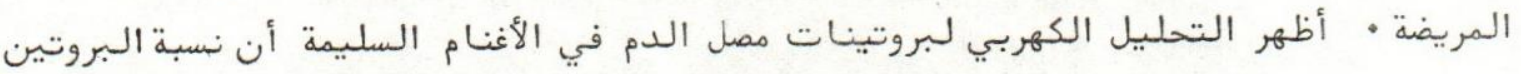

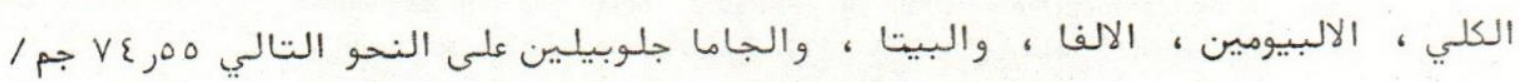

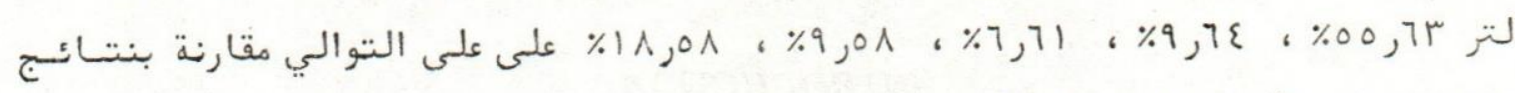

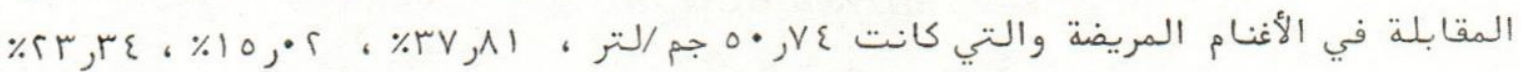
• • 
Dept. of Vet. Med.,

Faculty of Vet. Med., Assiut University,

Head of Dept. Prof. Dr. I.S. Abdallah.

\title{
ELECTROPHORETIC PATTERN OF OVINE BLOOD SERUM PROTEINS IN CASES OF NECROTIC LIVER DISEASE
}

(With 2 Tables \& 4 Figs.)

\author{
By \\ A. EL-SEBAIE and A. AMER \\ (Received at 11/7/1987)
}

\begin{abstract}
SUMMARY
This study was carried out on 35 native breed Osimi sheep, Ten animals were aparantly healthy and kept as control. Twenty Five sheep were disease and showed a signs of liver illness in the form of depression aneroxia, diarthea or constipation and in late stage recumbency and death. The mean values for serum total protein, Albumen, $\alpha_{1}, \alpha_{<} B$ and -globulin in healthy sheep were $74.55 \mathrm{~g} / 1 \quad 55.63 \%, 9.61 \%, 9.58 \%$ and $18.58 \%$ respectively while in diseased sheep the values were $50.47 \mathrm{~g} / \mathrm{i}, 37.81 \%, 15.02 \% 23.34 \%, 23.82 \%$ and 23.82 respectively.
\end{abstract}

\section{INTRODUCTION}

Many clinical laboratories have attemped the use of the changes observed in the quantitave and qualitative composition of the plasma protein for spesific diagnosis of the discase (CORNELIUS and KANEKI, 1960). Alleration that have been observed, have only served to demonstrate the state of the subject under study of particular time (INFRAN, 1967).

The abnormalities that are observed in plasma proteins can be grouped into number of patterns which characteize entire group of pathological states. These conditions are acute inflamation, chronic inflamatory and proliferative processes liver and biliary disorders, nephrotic syndrome and carcinomas.

Since the liver plays a central role in both anabolism and catabolism of plasma proteins, its not unreasonable to expect that plasma proteins analysis would be usuful in detecting liver injury (SCHALM, 1975). Unfortunately, protein fraction is of tittle value in detecting the degree of the lost function, of the establishing presence of parenchymal damage (SCHALM, 1970).

Liver damage does produce charactestic changes in plasma protein, however these changes appear late in the processe and may be more prognostic than diagnostic (SCHALM, 1975). Hypoprotenaemia commonly observed in hepatic diseases parasitic infestion, kidney disease and febrile diseases causes breakdown of endoganae protein (CORNELIUS, 1960). Generally the most. striking changes in disease is observable as decrease in the albumin fraction. The decrease may be the result of an inhibition in the synthesis or more rapid catabolism or it may be due to an increase in the concentration of globulin (HERZ and HOD, 1969, LARSON \& KENDALL, 1957). Moreover changes in $\gamma$-globulin reflects the response of reticuloendothilial system of antigens and these appear to be correlation between the concentration of $\gamma$-globulin and antiboey titer. The case is so in most infoctions with perhaps-the exception of those of viral etiology (DIMOPOULLOS, 1961).

Assiut Vet.Med.J. Vol. 19, No. 37, 1987. 


\section{EL-SFBAIE and AMER}

Necrotic hepatitis (Black disease) is mainly a disease of sheep, but in some areas it is aiso of significance in cattle stecrs. The disease is usually caused by $\mathrm{Cl}$.novyi and precipitated by invasion of liver by immature liver fluke (BAGADI and SEWELL, 1974).

Due to the great destructive effect of the disease on the liver cell, attention in the present investigation was paid to study the extent of changes in total serum proteins, and serum proteins electrophoresis in spontanous cases of necrotic liver disease in sheep.

\section{MATERIAL and METHODS}

In this study 35 native - breed Osimi sheep of both sexes were included. The animals were belonging to El-Hawatka station for animal production.

Twenty-five sheep showed the signs of illness in the form of depression, fever, anorexia in some cases recumbency while ten apparently healthy sheep were kept as a control.

Blood sampies were collected from each animal by means of jugular veinpuncture in strile dry and clean centrifuge tube. Serum was seperated by the ordinary method of veterinary hematology serum total proteins was estimated using test kits (BioMerux-France) and measured by Bye-unicum spectrophotemeter 8800 at wave length $546 \mathrm{~nm}$.

Fractionation of serum proteins was carried out using 0.8 ul of serum by Hamlton syringe and agarose film. The film was then processed fro approximately 35 minutes using $95 \mathrm{ml}$ of universal barbital buffer in each chamber of cells. At completion of the electrophoretic seperation the film was placed in $200 \mathrm{ml}$ of amido-black $10 \mathrm{~B}$ working solution for 15 minutes removed from the stain solution and then rinsed in $20 \mathrm{ml}$ of $5 \%$ acetic acid clearing solution using magentic stirres operating for 30 seconds.

The film was then compeletly dried for 20 minutes then allowed cool at room temperature, then washed in $5 \%$ acetic acid clearing solution to clear the excess stain proior to drying for one minute with agitation. It is then transfered to a second stirr stain dish contain $5 \%$ acetic acid solution, tinsed again for one minute, untile the excess stain is removed and dried for 15 minutes. Densitometry of the stained film was performed using DCD - 16 digital computing densitometer Gelman instrument company fitted with $520^{\circ} \mathrm{nm}$ interfrence filter. The values of optical density were plotted automatically by the aid of the instrument. The results were expressed by tacking as zero the migeration of gamina globulin and as 100 that of the albiumin.

\section{RESULTS}

Clinical observation of diseased sheep revealed anorexia, depresion, fever and intermittent diarrhoer and constipation. In some cases the animals unwill to move and recumbant. Such clinical manifectations were concised to liver affection and previausly diagnosed as necrotic. Liver disease (black disease) associated with cl. novyi infection and accompained with migration of immature forms of livet fluke (EL-SEBAIE, et al. 1987).

Results of total serum proteins and protein electrophoresis of healthy and diseased sheep were presented in table $(1 \& 2)$ and figures $(1,2,3 \& 4)$.

Mean values of serum total protein, Albumin, $\alpha-B$ and $\gamma$-globulin in healthy sheep were $74.55 \mathrm{~g} / 1$ 55.63\%, $9.69 \%, 6.61 \%, 9.581 \%$ and $18.58 \%$ respectively, while the Albumin/globulin

Assiut Vet.Med.J. Vol. 19, No. 37, 1987. 


\section{PROTEIN ELECTROPHORESIS IN LIVER DISEASE}

ratio was 1.256 . These values for disease sheep were $50.47 \mathrm{~g} / 173.81 \%, 15.02 \%, 23.34 \%, 23.82 \%$ respectively and the $A / G$ ratio was 0.61 .

\section{DISCUSSION}

In spite of the great range of total serum proteins mentioned after different authers, it is clear here to mention that the mean value of serum proteins in healthy individual lied with the range and accepted with the results published after CORNELLIUS (1960), CORNELLUS and KANEKO (1968), DOXEY (1978) and HASSAAN, et al. (1984).

The results of serum protein electrophoresis are in close agreement with those reported by CORNELLUS (1960), and HASSAAN, et al. (1984). On the other hand our results disagreed with the findings of SCHALM (1970). Conserning the Alpha and Beta globulin ratio-, such varitions could be due to the methods adopted.

Screening the data of serum protein in diseased sheep, there is a strong evidence of significant hypoproteinaemia $(50.47 \mathrm{~g} / 1)$ in contrast to mean values of healthy group (47.55 $\mathrm{g} / \mathrm{l}$ ). Such drop in the mean value of total serum protein could be attributed to the faliure of the liver for protein sunthesis under the influence fo $\mathrm{cl}$. infection or due to excessive liver cell damage during the migeration of liver fluke (CORNELLUS, 1960; CORNELLUS and KANEKO, 1968 and SCHALM, 1970). Hypoalbumenaemia (37.81\%) is the constant finding in individuals showing the signs of necrotic liver disease. This finding is accepted with CORNELLUS (1960). The author refered such atteration in blood serum albumin to retarded protein synthesis from such common clinical hepatic necrosis and cirrohsis due to spesific cause.

Mean value of gamma globulin is markedly increased (23.83\%) in diseased group. It is wellknown that increase in $\gamma$-globulin value refects the response of reticuloendothilial system to the causitive antigen (DIMOPOULLOS, 1961). Due to the marked decrease in allumin concentration and marked increase in value of serum globulin in diseased sheep, the ratio is consequently decreased of compared with healthy cones.

\section{REFERENCES}

Bagadi, H.O. and Sewell, M.M.H. (1974): Influence of post mortum analysis on the diagnosis of infectious necrotic hepatitis (black disease) Res. Vet. Sci. 17: 320-322, 1974.

Cornelius, C.E. (1960): Serum protein in Veterinary clinical diagnosis west Vet. 7: 77-80.

Cornellus, C.E. and Kaneko, J.J. (1968): Clinical biochemistry of domestic animal A cademic press, New York p. 276.

Dimopoullos, G.T. (1961): Serum protein and antibody studies in viral disease A review Ann. N.Y. Acad. Sci. 94: 149.

Doxey, D.L. (1978): Veterinary clinical pathology Baliere, tindall, London p. 198.

El-Sebaie, A.; K. lbrahim; A. Nafady and A. Tamawy (1987): Clinical, laboratory and histopathological observations on necrotic hepatitis in sheep (in press).

Hassaan, N.K.; A. El-Sebaie, and A. Amer (1984): Studies of the serum proteins in apparently healthy sheep, lambs and goat. Assiut Vet. Med. J. 12: 23: 175-180.

Herz, A. and Hod, I. (1969): Albumen, Alpha globulin ratio in various physiological state in cattle Brit. Vet. J. 125: 326-330.

Infran, M. (1967): The electrophoretic pattern of serum protein in normal animals. Res. Vet. Sci. 8: $137-142$. 


\section{EL-SEBAIE and AMER}

Larson, B.L. and Kendall, K.H. (1957): Changes in spesific blood serum protein levels associated with partiurition in bovine. J. Dairy Sci. 40-659.

Schalm, O.W. (1970): Clinical significance of serum protein concentration. J. Amer. Vet. Med. Ass. 157: 1627.

Schaim, O.W. (1975): In veterinary hematology 3rd ed. Leg. Feibiger philadelphia.

Table (1)

Serum total protein and serum protein electrophoresis in healthy sheep

\begin{tabular}{|c|c|c|c|c|c|c|c|c|}
\hline No & $\begin{array}{c}\text { T. } \\
\text { Protein } \\
\mathrm{g} / 1\end{array}$ & Alb. & $\alpha_{1}$ & $\propto 2$ & $B_{1}$ & $\mathrm{~B}_{2} \underset{\text { globulin }}{\gamma-}$ & Globulin & $A / G$ \\
\hline 1 & 75.31 & 56.70 & 9.60 & 8.4 & 6.60 & 18.70 & 43.34 & 1.30 \\
\hline 2 & 71.46 & 58.30 & 8.60 & 9.20 & 6.50 & 17. & 41.44 & 1.40 \\
\hline 3 & 78.07 & 55.10 & 11.40 & 5.30 & 13.49 & 19.71 & 49.9 & 1.10 \\
\hline 4 & 70.32 & 57.40 & 12.30 & 3.71 & 9.79 & 16.80 & 42.60 & 1.34 \\
\hline 5 & 73.05 & 50.90 & 9.90 & 9.70 & 9.90 & 19.60 & 49.1 & 1.03 \\
\hline 6 & 74.60 & 51.94 & 8.60 & 6.80 & 13.90 & 18.71 & 48.01 & 1.08 \\
\hline 7 & 75.30 & 55.60 & 7.35 & 3.90 & 15.21 & 17.94 & 44.4 & 1.25 \\
\hline 8 & 76.10 & 58.30 & 12.4 & 2.4 & 10.30 & 16.60 & 41.7 & 1.39 \\
\hline 9 & 74.50 & 53.79 & 7.73 & 8.30 & 5.35 & 19.83 & 41.2 & 1.30 \\
\hline 10 & 77.80 & 58.30 & 8.00 & 8.4 & 4.7 & 20.60 & 42.3 & 1.378 \\
\hline$x$ & 74.551 & 55.633 & 9.648 & 6.611 & 9.581 & 18.58 & 44.39 & 1.256 \\
\hline S.D & \pm 2.487 & \pm 2.694 & 1.825 & 2.59 & 3.737 & 1.36 & 3.34 & 0.137 \\
\hline
\end{tabular}


PROTEIN ELECTROPHORESIS IN LIVER DISEASE

Table (2)

Serum total protein and protein electrophoresis in sheep with necrotic liver disease

\begin{tabular}{|c|c|c|c|c|c|c|c|c|c|}
\hline & $\begin{array}{c}\text { Total } \\
\text { protein }\end{array}$ & $\begin{array}{c}\text { Alb. } \\
\%\end{array}$ & $\begin{array}{c}\alpha-1 \\
\%\end{array}$ & $\underset{\%}{-2}$ & $\begin{array}{l}\mathrm{B}_{1} \\
\%\end{array}$ & $\mathrm{~B}_{2}$ & $\begin{array}{l}x \\
\%\end{array}$ & $\begin{array}{c}\text { Total } \\
\text { Glob. } \\
\%\end{array}$ & $\begin{array}{c}A / G \\
\%\end{array}$ \\
\hline 1 & 57.20 & 31.78 & 6.17 & & 39.46 & & 22.39 & 68.02 & 0.46 \\
\hline 2 & 29.30 & 28.55 & 15.18 & & 31.35 & & 24.92 & 71.45 & 0.39 \\
\hline 3 & 50.73 & 34.06 & 11.30 & & 26.04 & & 28.60 & 65.94 & 0.51 \\
\hline 4 & 33.82 & 29.50 & 13.10 & & 33.39 & & 24.01 & 70.50 & 0.40 \\
\hline 5 & 41.80 & 34.63 & 16.34 & & 27.33 & & 21.70 & 60.37 & 0.57 \\
\hline 6 & 59.85 & 40.9 & 20.40 & & 19.00 & & 19.70 & 59.10 & 0.69 \\
\hline 7 & 47.69 & 31.01 & 9.07 & & 23.62 & & 36.30 & 68.99 & 0.44 \\
\hline 8 & 59.28 & 34.52 & 12.22 & & 23.07 & & 30.19 & 65.48 & 0.52 \\
\hline 9 & 58.52 & 31.94 & 21.62 & & 26.63 & & 19.81 & 68.06 & 0.46 \\
\hline 10 & 53.90 & 31.94 & 18.00 & & 23.59 & & 26.44 & 65.61 & 0.52 \\
\hline 11 & 48.60 & 40.01 & 17.34 & & 24.69 & & 17.96 & 59.99 & 0.66 \\
\hline 12 & 49.03 & 30.55 & 13.03 & & 20.55 & & 35.87 & 69.97 & 0.43 \\
\hline 13 & 48.71 & 35.76 & 14.20 & & 22.74 & & 27.30 & 64.24 & 0.55 \\
\hline 14 & 44.30 & 44.10 & 14.10 & & 18.73 & & 23.07 & 55.90 & 0.78 \\
\hline 15 & 53.10 & 41.70 & 11.29 & & 10.14 & & 26.87 & 58.30 & 0.71 \\
\hline 16 & 56.7 & 38.90 & 23.31 & & 16.38 & & 21.51 & 61.18 & 0.63 \\
\hline 17 & 57.6 & 44.70 & 9.14 & & 19.10 & & 27.06 & 55.30 & 0.80 \\
\hline 18 & 38.90 & 42.30 & 17.22 & & 18.70 & & 21.88 & 58.28 & 0.72 \\
\hline 19 & 34.60 & 41.20 & 17.05 & & 25.88 & & 15.87 & 58.80 & 0.70 \\
\hline 20 & 63.70 & 51.9 & 4.98 & & 26.31 & & 16.81 & 48.10 & 1.07 \\
\hline 21 & 47.13 & 38.60 & 19.23 & & 18.83 & & 23.35 & 61.41 & 0.62 \\
\hline 22 & 56.75 & 40.70 & 21.81 & & 17.30 & & 20.19 & 59.30 & 0.68 \\
\hline 23 & 55.10 & 43.20 & 18.24 & & 18.86 & & 19.70 & 56.8 & 0.76 \\
\hline 24 & 46.80 & 41.30 & 20.30 & & 19.7 & & 18.70 & 58.70 & 0.70 \\
\hline 25 & 59.70 & 39.06 & 13.49 & & 22.11 & & 25.34 & 60.94 & 0.64 \\
\hline$x$ & 50.479 & 37.810 & 15.02 & & 23.34 & & 23.82 & 62.029 & 0.616 \\
\hline S.D & \pm 9.50 & 5.683 & 4.80 & & 5.45 & & & 2.40 & 0.155 \\
\hline
\end{tabular}

Assiut Vet.Med. J. Vol. 19, No. 37, 1987. 


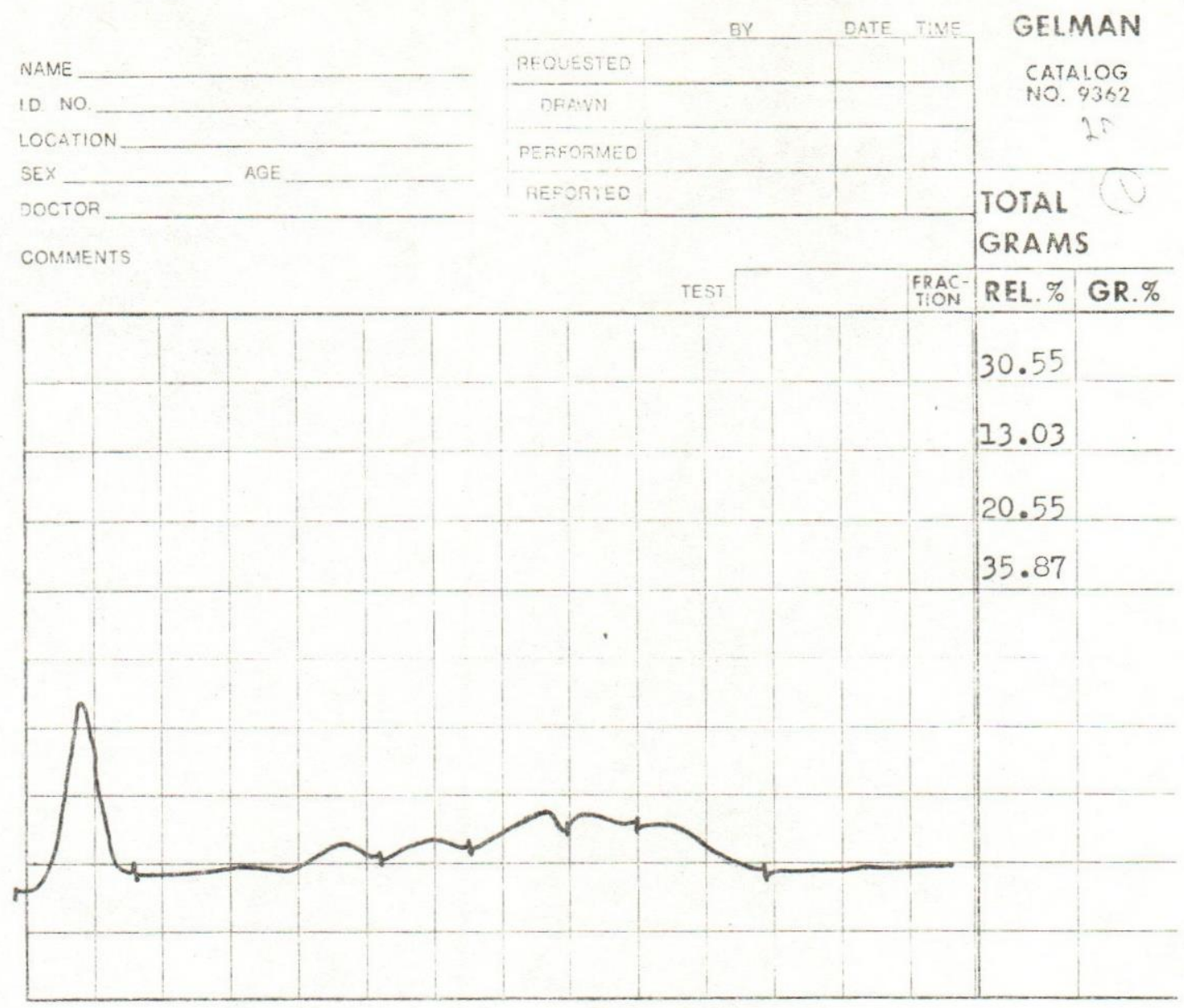

NAME

1.D. NO.

LOCATION

SEX

SOCTOA

CONMENTS

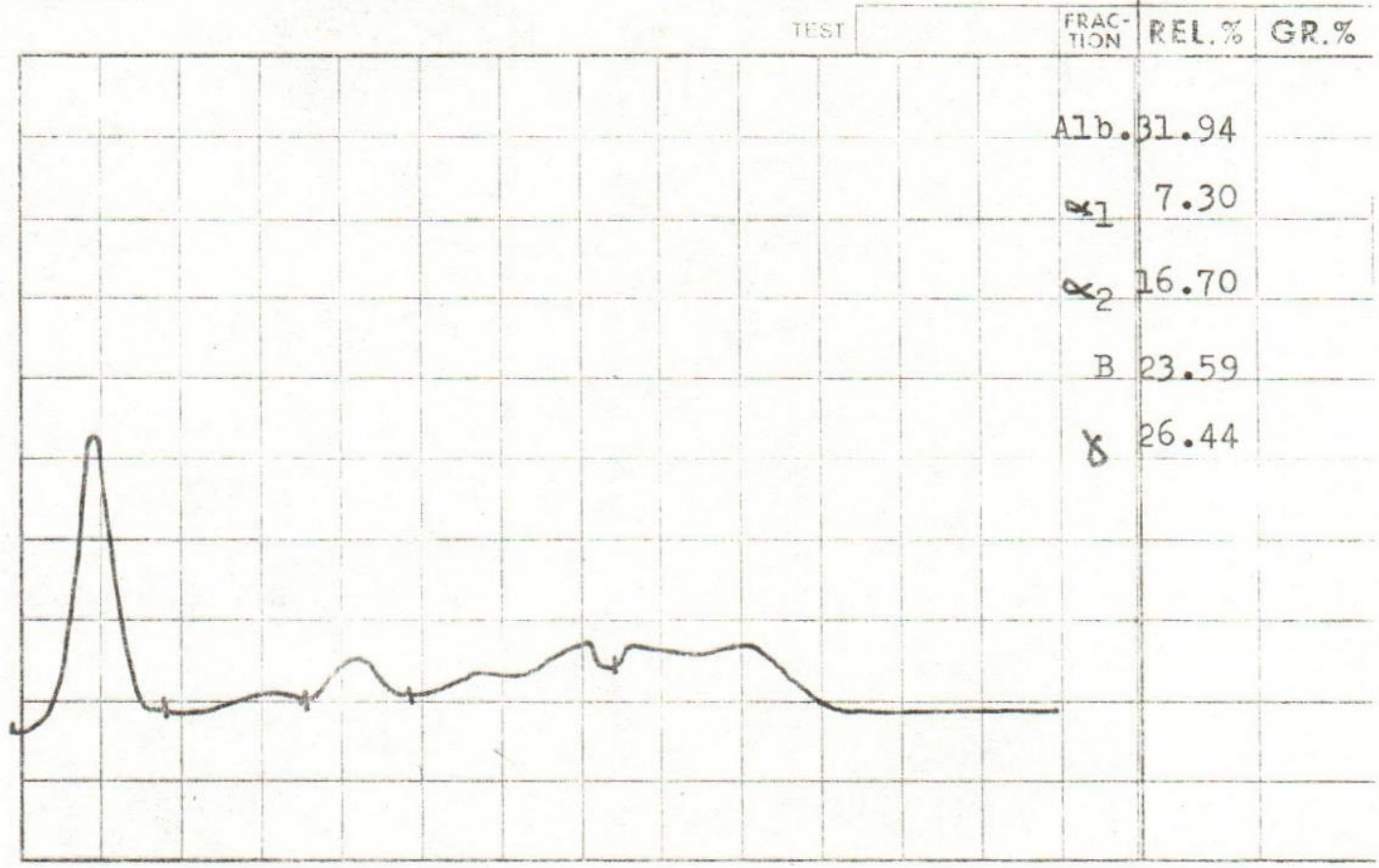

Fig. (1,2): Blectrophoretic pottern of serum proteins in heelthy sheep 
NAME BT-Hawatka

I.D. NO.

LOCATION

SEX AGE

DOCTOR DeDt, of animei med.

COMMENTS

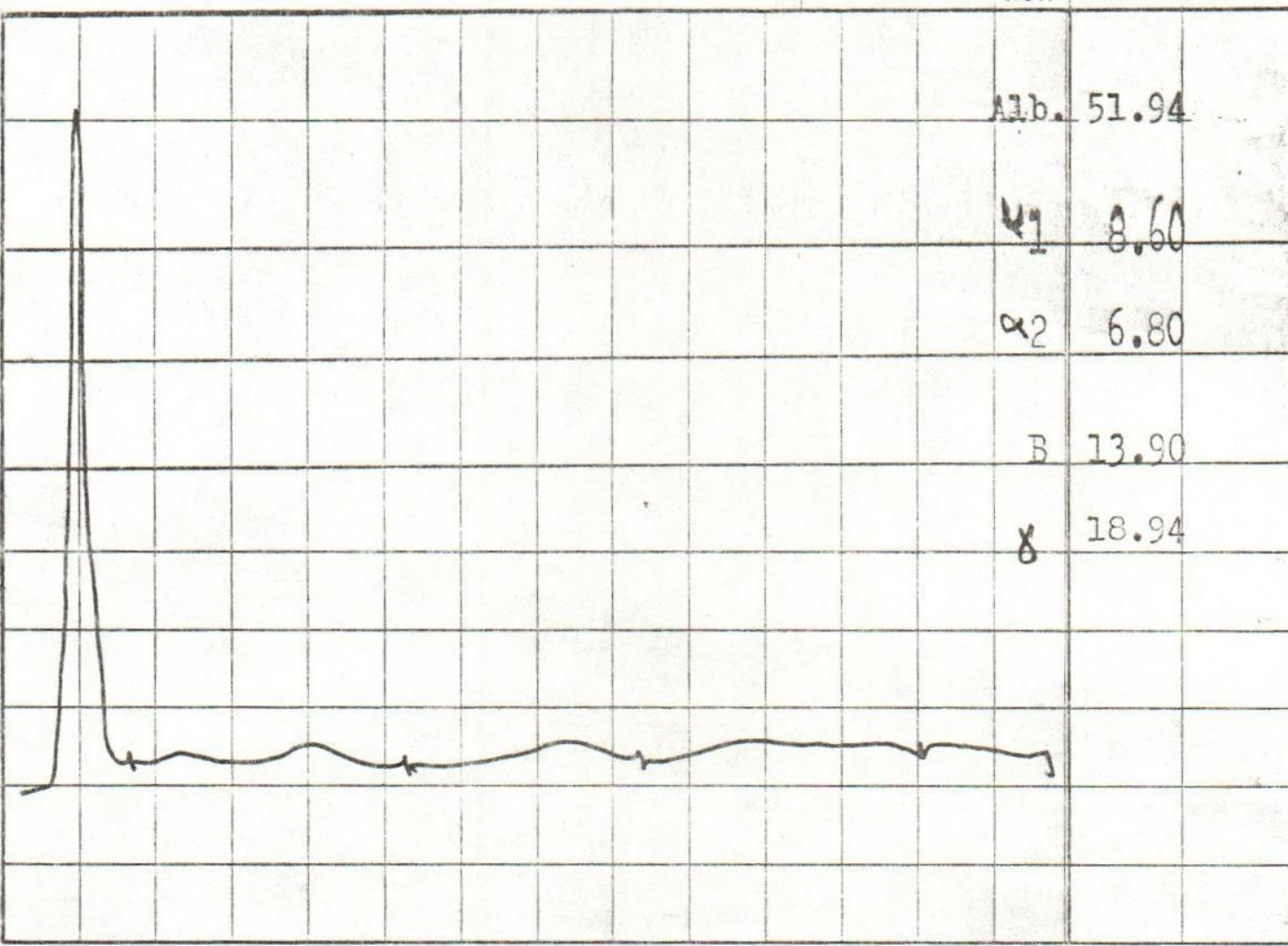

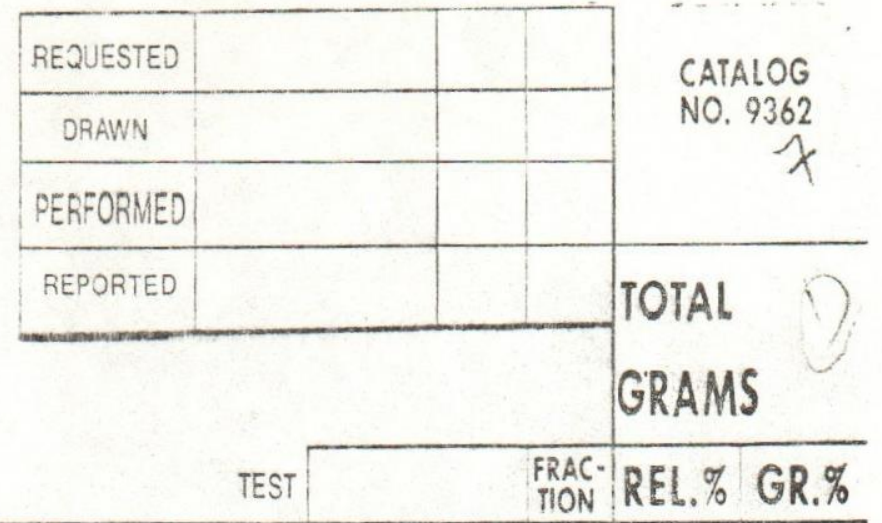

NAME TI-Hemetks

I.D. NO.

LOCATION

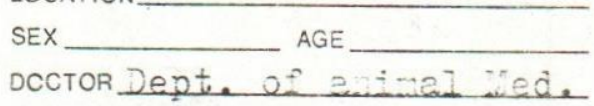
COMMENTS

\begin{tabular}{|c|c|c|c|c|}
\hline & & DATE & TIME & GELMAN \\
\hline REQUESTED & & & & \multirow{3}{*}{$\begin{array}{l}\text { CATALOG } \\
\text { NO. } 9362\end{array}$} \\
\hline DRAWN & & & & \\
\hline \multicolumn{4}{|l|}{ PERFORMED } & \\
\hline REPORTED & & & & \multirow{2}{*}{$\begin{array}{l}\text { TOTAL } \\
\text { GRAMS }\end{array}$} \\
\hline \multicolumn{4}{|c|}{. } & \\
\hline & TEST & & $\begin{array}{l}\text { FRAC. } \\
\text { TION }\end{array}$ & REL.\% GR.\% \\
\hline
\end{tabular}

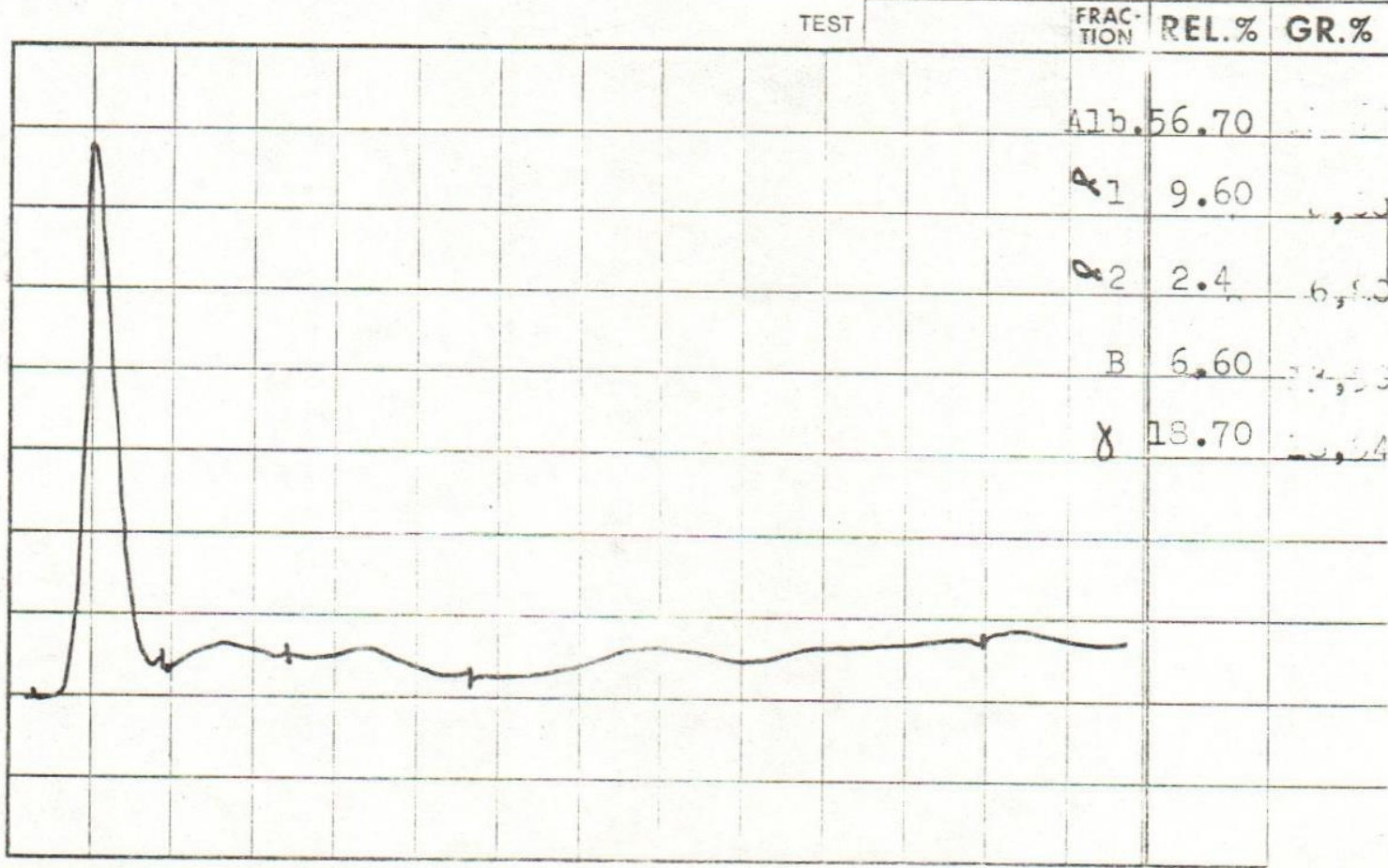

